Pétervári Máté

\title{
A SZOLGABÍRÁK HATÁSKÖRÉNEK BEMUTATÁSA AZ 1870: XLII. TC. RENDELKEZÉSEI ALAPJÁN ${ }^{1}$
}

\author{
The Authority of District Administrators on the Basis of Act XLII of 1870 in Hungary
}

Dr. Pétervári Máté, adjunktus, Szegedi Tudományegyetem Állam- és Jogtudományi Kar Magyar Jogtörténeti Tanszék, petervari.mate@juris.u-szeged.hu

A magyar területi önkormányzatok müködését átszervező 1870: XLII. tc. jelentős változást hozott a 13. század második felében létrejött szolgabírói tisztség vonatkozásában is, ugyanis a köztörvényhatósági törvény rendelkezéseinek értelmében a törvénynek való megfelelést biztositó belügyminiszteri irányítás mellett a vármegyék újraszabályozták alsó középszintü közigazgatási szervezetüket. A szolgabírák hatásköréröl csupán egyetlen szakaszban rendelkezett a jogalkotó, amelynek következtében a vármegyék szabadon határozhatták meg járási tisztviselöik feladatait. A törvény végrehajtása alkalmával valósulhatott meg az 1869: IV. tc.-nek a közigazgatást és az igazságszolgáltatást elválasztó rendelkezése is. A hat évszázada törvénykezési feladatokat ellátó vármegyei tisztviselö ezáltal veszítette el bíráskodási feladatait. Tanulmányomban az 1870. évi XLII. tc. végrehajtására alkotott vármegyei szabályzatok alapján vizsgáltam a szolgabírák hatáskörét a levéltári források segítségével (Magyar Nemzeti Levéltár Országos Levéltára Belügyminisztériumi iratok C/Általános iratok K150 117., 118. csomók), így a partikuláris operátumok feldolgozásával igyekeztem egységes képet nyújtani a szolgabírák munkájáról.

\section{KulcsszavaK:}

dualizmus, járás, közigazgatás és igazságszolgáltatás elválasztása, községek feletti felügyelet, törvényhatósági törvény, újoncozás, vármegyék

Act XLII of 1870 (the first Hungarian Municipal Act) reorganised the middle level of public administration of Hungary. This act transformed the administration level under the counties and the districts, too. The counties had rights to regulate their districts, the operation of which were

\footnotetext{
A mű a KÖFOP-2.1.2-VEKOP-15-2016-00001 azonosítószámú, „A jó kormányzást megalapozó közszolgálat-fejlesztés" elnevezésű kiemelt projekt keretében működtetett Államtudományi Kutatóműhely keretében, a Nemzeti Közszolgálati Egyetem felkérésére készült.
} 
checked by the Royal Ministry of Interior. The districts were directed by the district administrators, whose authorities were determined by only one article in the act. For this reason, the counties were able to form the duties of the district administrators in detail. The execution of this act realised the separation of jurisdiction and public administration in the level of districts in Hungary. In my paper, I examined the authority statutes of the counties, and I presented the duties of the district administrators based on archival material (National Archives of Hungary, Ministry of Interior K150, bundles 117 and 118) after the execution of the Act XLII of 1870.

\section{KEYWORDS:}

counties, district, dualism, Municipal Act, recruitment of soldiers, separation of jurisdiction and public administration, supervision of the communities 


\section{A SZOLGABÍRÁK HATÁSKÖRE A KÖZTÖRVÉNYHATÓSÁGI TÖRVÉNYBEN}

A közigazgatási szervezet modernizálása a kiegyezés után hivatalba lépő Andrássy-kormányra hárult, ${ }^{2}$ mivel az áprilisi törvények ismételt hatályba léptetése ennek megvalósítására alkalmatlan volt. Az 1848: XVI. tc. csupán ideiglenes rendelkezéseket tartalmazott, valamint azt a célkitüzést, hogy a vármegyét a népképviselet elvével kívánják összhangba hozni. ${ }^{3}$ A köztörvényhatóságokról szóló 1870: XLII. tc. és a községi törvény (1871: XVIII. tc.) országgyülési elfogadásával végül sikeresen lezárult a magyar végrehajtási szervezet kiépítése, ${ }^{4}$ bár a vármegyék és a törvényhatósági jogú városok egy törvényben való szabályozása vagy a virilizmus bevezetése komoly vitákat generált. ${ }^{5} \mathrm{~A}$ vármegyei törvényhatóságok számára a köztörvényhatósági törvény viszont biztosította, hogy önkormányzati jogköreik gyakorlásával maguk hozhassák létre közigazgatási szervezetük részletes szabályozását. A vármegyékben működő állandó bizottmányokat bízta meg azzal, hogy egy küldöttséget állítsanak fel a föispánok elnökletével, amelyek a szükséges operátumokat kidolgozták. ${ }^{6}$ Az így elfogadott tervezeteket az állandó bizottmányoknak kellett jóváhagyniuk, majd a belügyminiszternek megerősítés céljából felterjeszteni.

E tervezetek között dolgozták ki a törvény 91 . \$-a értelmében a vármegyéken belüli alsó középszintű közigazgatási egységek, a járások beosztását, valamint a tisztviselők hatáskörét, fizetését és napidíját. A törvény mindössze egyetlen szakasz erejéig (61. §) rendelkezett a szolgabírákról, így a szolgabírói hivatalokat e keretek között a vármegyék szabadon alakíthatták ki. A jogalkotó ebben általános jelleggel szabályozta a járás élén álló tisztviselők hatáskörét, miszerint felügyel a hatósága alatt álló községekre, és gyakorolja azon jogokat és teljesíti azon kötelességeket, amelyeket a törvény és a szabályrendeletek ráruháznak.7 A községek működésében betöltött kiemelt szerepén túl, így a törvényhozó feladatköreiket részletesen nem határozta meg. Emiatt a már említett vármegyei munkálatok szabályozhatták pontosan a szolgabírák hatáskörét. A közigazgatás polgári

Székely Tamás: A közigazgatás átalakításának programja. Modernizáció és nemzetállam-építés a dualizmus korában. In Csibi Norbert - Schwarczwölder Ádám (szerk.): Modernizácó és nemzetállam-épités. Haza és/vagy haladás dilemmája a dualizmus kori Magyarországon. Pécs, Kronosz, 2018. 165-180. 165.

3 Stipta István: Az első polgári kori vármegyetörvény (1848:XVI. tc). Acta Universitatis Szegediensis: Acta Juridica et Politica, 42. (1992), 5. 3-34.3-4.

4 Máthé Gábor: Polgári kori közigazgatásunk történeti jellemzői. In Imre Miklós - Lamm Vanda - Máthé Gábor (szerk.): Közjogi tanulmányok Lörincz Lajos 70. születésnapja tiszteletére. Budapest, Aula, 2006. 262-267. 263.

Varga Norbert: A föispáni tisztség bevezetése Debrecen és Szeged szabad királyi városokban a köztörvényhatósági törvény alapján. In Mezey Barna - Révész T. Mihály (szerk.): Ünnepi tanulmányok Máthé Gábor 65. születésnapja tiszteletére. Budapest, Gondolat, 2006. 606-623. 606-607.; Varga Norbert: A virilizmus bevezetése és a cégek virilis jogának megítélése Szegeden. Jogtörténeti Szemle, 13. (2011), 1. 43-47. 43.; Varga Norbert: A föispán és a városi közigazgatás reformja a polgári korban. Pro Publico Bono - Magyar Közigazgatás, (2018), 1. $180-199.188$.

6 Stipta István: Intézménytörténeti adalékok az 1870:XLII. tc. végrehajtásához. In Tóth Károly (szerk.): Emlékkönyv Dr. Cséka Ervin egyetemi tanár születésének 70. és oktatói munkásságának 25. évfordulójára. Szeged, JATE, 1992. 481-494. 485-486.

Márkus Dezső: Ungarisches Verwaltungsrecht. Tübingen, Mohr, 1912. 308. 
átszervezése ebben jelentős változásokat idézett elő, mivel az 1869: IV. tc. a közigazgatás és az igazságszolgáltatás elválasztásával leválasztotta a járást vezető tisztviselőkről a törvénykezési hatásköröket. ${ }^{8}$

A szolgabírák feladatait a rendi korszakban Zsoldos Ignác, a közigazgatási jogtudomány első akadémikusa, gyüjtötte össze, aki 1842-ben kétkötetes monográfiát jelentetett meg, külön bemutatva a közigazgatási (a korszak szóhasználata szerint politikai) és az igazságszolgáltatási hatásköröket. ${ }^{9}$ Emellett pedig 1865-ben Kassay Adolf jelentetett meg egy kézikönyvet a gyakorló járási tisztviselők számára. ${ }^{10}$ A két erről szóló munka azonban még a kiegyezést megelőző állapotokat rögzítette, így a törvényhatósági törvény hatálybalépését követően érdemes megvizsgálni a szolgabírák hatásköreit. Ezt a Magyar Nemzeti Levéltár Országos Levéltárában megtalálható, Belügyminisztérium számára felterjesztett vármegyei tervezetek alapján kívánom felderíteni.

A szolgabírák hatáskörét azonban nem minden törvényhatóság szabta meg. Arad vármegye elegendőnek találta az 1870: XLII. tc. szolgabírákra vonatkozó rendelkezéseit. ${ }^{11}$ Csanád vármegye pedig ezt a következő indokkal mellőzte: „A tiszti kar munka köre meghatározásánál [...] csak a szűk körvonalazásra szorítkoztunk, ’s a tisztviselőt működésében rideg §ok tömkellegével zsibbasztani nem akartuk. A törvént és fennálló szabályrendeleteket mindenütt figyelembe véve alkottuk a határozott szövegü utasitást, részletekre csak ott bocsájtkozva a hol a rendeletek kül alakja és az ügymenet gyorsasága megkivánta, jól tudván, hogy mennél több a szabály annál több a kibuvó ajtó." ${ }^{12}$ A vármegyék jelentős része azonban nem találta elegendőnek a törvényhatósági törvény azon rendelkezését, hogy a szolgabíráknak a törvények és szabályrendeletek által hozzájuk utalt jogokat és kötelezettségeket kell gyakorolniuk, így a továbbiakban e törvényhatóságok hatásköri szabályzatait vizsgálom.

A szolgabíró működése során az alispántól kapta utasításait, és az államigazgatási ügyekben is az alispán közvetítette irányába a kormányzat intézkedéseit. ${ }^{13} \mathrm{~A}$ kormányrendeletek végrehajtása a járásukban a szolgabírák felelőssége volt. ${ }^{14} \mathrm{~A}$ járást vezető

8 Stipta István: A magyar bírósági rendszer története. Debrecen, Multiplex Media - Debrecen U. P., 1998. 122.; Megyeri-Pálffi Zoltán: A Hajdúböszörményi Járásbíróság megszervezésének és elhelyezésének története. In Megyeri-Pálffi Zoltán (szerk.): A jogszolgáltatás története Hajdúböszörményben. Debrecen, Debreceni Törvényszék, 2018. 59-77. 59.

9 Zsoldos Ignác: A’ szolgabírói hivatal. Közrendtartási rész. Pápa, Református Főiskola, 1842; Zsoldos Ignác: A szolgabírói hivatal. Törvénykezési rész. Pápa, Református Főiskola, 1842.

10 Kassay Adolf: A szolgabirák és megyei esküdtek hatásköre és teendői. Pest, Stolp Károly, 1865.

11 „Szükségesnek találjuk végül tiszteletteljesen megérinteni miszerint az alispán, ügyész, szolgabíró és jegyző munka körét illetőleg, azért nem dolgoztunk ki tervezetet, mivel a törvényben már kivan jelölve." Magyar Nemzeti Levéltár Országos Levéltára, Belügyminisztériumi iratok (a továbbiakban: MNL BM) K150 C/ Általános iratok 117. 17731/1871.-Arad vármegye.

12 MNL BM K150 117. 17803/1871.

13 „[M]iután megyénk közönsége a járási sz[olga]birókat eredetileg is, most is, egymástól függetlennek tervezte, óhajtja, kik egyedül a megyétől vagy alispántól vegyék meghagyásaikat." - MNL BM K150 118. 31986/1871.Hont vármegye; Boncz Ferenc: A magyar közigazgatási törvénytudomány kézikönyve a törvényhozás legújabb állása szerint. I. k. Budapest, Athenaeum, 1876. 128 e).

14 MNL BM K150 117. 21272/1871.-Doboka vármegye. 
tisztségviselő önállóan hozott határozataival szemben szintén az alispánhoz lehetett fellebbezni, majd onnan a belügyminiszterhez lehetett fordulni a törvényhatósági törvény értelmében. ${ }^{15} \mathrm{~A}$ szolgabírák emellett jogosultak voltak a törvényhatósági bizottság közgyülésein részt venni, amelyen szavazati joguk is volt.

Gömör és Kis-Hont vármegye szolgabírói hivatalára vonatkozó tervezetében részletesen bemutatta, hogy melyek az egy ember erejét meghaladó „föszolgabírói” teendők. ${ }^{16}$ (A vármegye a belügyminisztériumi korrekciót megelőzően a később javított főszolgabírói elnevezést alkalmazta.) Szeptemberben a közmunka és az újoncösszeírás, januárban és februárban pedig a községi, a gyámi számadások és az előköltségvetések vizsgálata jelentős mértékben leterhelte a járási tisztviselöket. Emiatt e hatáskörök felderítésével érdemes megkezdeni a szolgabírák feladatainak vizsgálatát.

\section{A SZOLGABÍRÁK KATONASÁGGAL KAPCSOLATOS TEENDÖI}

A véderőtörvény alapján az ország fegyveres ereje a hadseregből, a haditengerészetből, a honvédségből és a népfelkelésből állt. A hadseregnek az Osztrák-Magyar Monarchia mindkét államának megvédése és belső rendjének biztosítása volt a feladata, míg a honvédség a hadsereget támogatta, és csupán Magyarországgal kapcsolatos hadi feladatokat látott el. A hadseregbe, a haditengerészetbe és a honvédségbe sorozottakat eltérő kötelezettségek terhelték, így az újoncokat külön is válogatták ki az egyes hadtestekbe.

A véderőről szóló 1868: XL. tc. és a hozzá kapcsolódó rendeletek határozták meg a szolgabírák hatásköreit a katonaállítás során. A vármegyékben a járási tisztviselők feladata volt a hadkötelezett korosztályban lévők összeírása a községi elöljárók közreműködésével. Ezt követően szintén a szolgabíráknak kellett lebonyolítani a sorshúzást, amelynek célja meghatározni azt a sorrendet, ami alapján a védkötelezettek a különböző hadtestekbe kerültek. A katonai szolgálattal kapcsolatos beadványok elintézése is a járási tisztviselők hatáskörébe tartozott. Az eljárás e részének megvalósítására sorozójárásonként augusztus 15-e és szeptember 30 -a között került sor. ${ }^{17}$

A szolgabíró az alispán, a föorvos és két megbízható személy mellett a közigazgatást képviselte a sorozóbizottságokban mint sorozási előadó. A sorozási bizottságoknak a rendes hadsereg és a honvédség részéről is voltak tagjaik. A legfontosabb feladatuk a besorozandók szellemi és testi képességeinek felmérése volt, valamint ez alapján beosztásuk a különböző hadtestekbe. Emellett e testületek bírálták el a katonai szolgálat alóli felmentéseket. ${ }^{18} \mathrm{Az}$ eljárás e szakaszát január 15-e és március 15 -e között bonyolították le,

MNL BM K150 117. 21272/1871.-Doboka vármegye; 22026/1871.-Felső-Fehér vármegye; 233. 28463/1873.Moson vármegye.

16 MNL BM K150 118. 23816/1871.

17 84. A magyar királyi honvédelmi ministerium körrendelete valamennyi törvényhatósághoz. 1869. 730-744.

18 86. A honvédelmi m. kir. ministerium körrendelete, valamennyi törvényhatósághoz a sorozási ügy törvényszerü foganatositása végett követendő eljárás részletezése tárgyában. 1869. 745-749. 
a hadseregbe pedig október 1-jével kellett jelentkezni. Az újoncozási teendők olyan fontosságúak voltak a szolgabírák életében, hogy e teendőket az összes törvényhatóság feltüntette. ${ }^{19} \mathrm{~A}$ járást vezető tisztviselőknek nem csupán a sorozási teendők voltak az egyedüli katonasággal kapcsolatos hatásköreik. ${ }^{20} \mathrm{~A}$ katonák elszállásolásának és élelmezésének megszervezése, ${ }^{21}$ a szabadságolt katonák, a póttartalékosok, illetve az ideiglenesen és véglegesen rokkantak nyilvántartása, valamint az előfogatokról való gondoskodás ${ }^{22}$ is hozzájuk tartozott. Fogaras vidék emellett kiemelte, hogy a katonai visszaélésekkel szemben a községek megóvása is a szolgabírák kötelessége. ${ }^{23}$

\section{A JÁRÁSI LAKOSSÁG KÖZMUNKA-KÖTELEZETTSÉGE}

A megyei lakosság az adó megfizetése mellett közmunkára is kötelezett volt. A közmunkaösszeírásokat szintén szeptember 30-áig kellett benyújtani az alispánnak. A szolgabíró az egyes községekben a községi elöljárók és két hites személy jelenlétében írta össze a fennálló közmunkatartozásokat, ${ }^{24}$ amelyek jegyében a lakosság útfelújítást, a hidak, gátak karbantartását végezte el a megyei mérnök közremüködésével. ${ }^{25}$ Emellett közveszély esetén a veszély elhárítására is igénybe vehették a közmunka-kötelezettek munkáját. A közmunkát pénzben is megválthatták. ${ }^{26} \mathrm{~A}$ kötelezettség végrehajtása a szolgabírák feladata volt, a közmunkák szabályozásáról szóló 1844: IX. tc. értelmében. Ezt a feladatkört szintén az összes törvényhatóság feltüntette a hatáskörröl szóló rendeletében. ${ }^{27} \mathrm{Az}$ ehhez kapcsolódó feladatok elvégzése érdekében Doboka, Sáros, Veszprém, Közép-Szolnok, Hunyad és Moson vármegye a szolgabírákra bízta a községi közlekedési utak felügyeletét és karbantartását, amelyben a községi elöljáróságok segítették. ${ }^{28}$ A szolgabíró az utak karbantartása miatt Doboka, Felső-Fehér, Sáros, Bereg, és Közép-Szolnok vármegyében az útibiztosokkal is

19 MNL BM K150 117. 21272/1871.-Doboka vármegye; 22026/1871.-Felső-Fehér vármegye; 21800/1871. -Fogaras vidék; 20826/1871.-Sáros vármegye; 118. 22592/1871.-Bereg vármegye; 32032/1871.-Gömör és KisHont vármegye; 22187/1871.-Közép-Szolnok vármegye; 22336/1871.-Veszprém vármegye; 233. 28463/1873.Moson vármegye.

20 Boncz (1876) i. m. 128 e).

21 MNL BM K150 117. 21272/1871.-Doboka vármegye; 118. 22592/1871.-Bereg vármegye; 32032/1871.-Gömör és Kis-Hont vármegye; 233. 28463/1873.-Moson vármegye.

22 MNL BM K150 117. 21272/1871.-Doboka vármegye; 21800/1871.-Fogaras vidék.

23 MNL BM K150 21800/1871.-Fogaras vidék.

24 Kassay (1865) i. m. 75.; Boncz (1876) i. m. 128 e); MNL BM K150 117. 21272/1871.-Doboka vármegye; 118. 23891/1871.-Hunyad vármegye.

25 MNL BM K150 117. 22026/1871.-Felső-Fehér vármegye; 118. 23891/1871.-Hunyad vármegye.

26 1871: XVIII. tc. 122. \$.

27 MNL BM K150 117.21272/1871.-Doboka vármegye; 22026/1871.-Felső-Fehér vármegye; 21800/1871.-Fogaras vidék; 20826/1871.-Sáros vármegye; 118. 22592/1871.-Bereg vármegye; 32032/1871.-Gömör és Kis-Hont vármegye; 23891/1871.-Hunyad vármegye; 22187/1871.-Közép-Szolnok vármegye; 22336/1871.-Veszprém vármegye; 233. 28463/1873.-Moson vármegye. 
szoros kapcsolatban volt. ${ }^{29}$ Közép-Szolnok és Doboka vármegyében emellett kötelesek voltak havonta a közmunka eredményéről az alispánnak jelentést tenni. ${ }^{30}$

\section{A KÖZSÉGEK ÉS A SZOLGABÍRÁK KAPCSOLATA}

A szolgabírói hatáskörök legnagyobb csoportja az 1871: XVIII. tc. alapján, valamint az 1870. évi XLII. tc. 61. \$ második fordulata szerint a községekhez kapcsolódott. A két törvény a szolgabírák szerepét a községekkel szemben csupán a felügyeletre szorította. A községi törvény három településtípust különböztetett meg: a kisközséget, a nagyközséget és a rendezett tanácsú várost. A szolgabírák hatásköre a kisközségekre és nagyközségekre terjedt ki, ${ }^{31}$ mivel a rendezett tanácsú városok önállóan látták el azokat a feladatokat, amelyeket a járást vezető tisztségviselők végeztek a többi településen.

Nehrebeczky Sándor miniszteri tanácsos a községi törvény országgyülési vitája során a szolgabíró gyámkodásaként definiálta ezt a tevékenységet, amelyet véleménye szerint határozottan igényelnek a községek. ${ }^{32}$ A törvény megszületése előtti állapotokat vizsgálva a községek számára ez óriási előrelépést jelentett, mert ezt megelőzően körvonalazható autonómiával nem rendelkeztek. Ennek jegyében kerülhetett a községekhez elöljáróiknak választási joga, amely ezt megelőzően a szolgabírák kijelölési jogához kötött volt. Ezt Tóth Vilmos belügyminiszter emelte ki felszólásában a Képviselőház 1871. március 22-ei ülésnapján. A korábbi állapotokat a következőképpen vázolta: „A mi pedig a községek belügyeit illeti, azok autonómiája mindnyájunk tudomása szerint, oly csekély volt, hogy az egész autonómiát tulajdonképen e két szóban lehetett összefoglalni: szolgabírói hatalom." 33

A szolgabírák a községek képviselő-testületének összeállításában vettek részt. E testületi szervek fele részben virilis (a legtöbb egyenes állami adót fizetők), fele részben választott tagokból álltak össze. ${ }^{34} \mathrm{~A}$ járást vezető tisztviselők így a virilisek névjegyzékét igazították ki. A képviselők választása során pedig kitűzte a választás időpontját, és választási elnökként lebonyolította azt. ${ }^{35} \mathrm{~A}$ választások jogszerűségét ellenőrző igazolóválasztmányok elnökei járásuk községeiben szintén a szolgabírák voltak. Emellett pedig közremüködtek a tisztújító szék alkalmával is, amelyen a községi elöljárókat választották. E vezető

$29 \quad$ MNL BM K150 117. 21272/1871.; 22026/1871.; 20826/1871.; 118. 22592/1871.; 22187/1871.

30 MNL BM K150 118. 22187/1871.; 117. 21272/1871.

31 „Ezekhez képest hatáskörükhöz tartoznak [a szolgabíráknak-P.M.]: a.) a kis és nagy községekre való közvetlen felügyelet."-MNL BM K150 118. 22592/1871.-Bereg vármegye.

32 Nagy Iván (szerk.): Az 1869-dik évi april 20-dikára hirdetett országgyülés képviselöházának naplója. XV. k. Pest, Légrády Testvérek, 1871. 131.

33 Nagy Iván (szerk.): Az 1869-dik évi april 20-dikára hirdetett országgyülés képviselőházának naplója. XV. k. Pest, Légrády Testvérek, 1871. 149.

34 Hencz Aurél: Területrendezési törekvések Magyarországon. Budapest, Közgazdasági és Jogi Könyvkiadó, 1973. 106.

35 Takács Imre: A járási tanácsok feladatai. Budapest, Közgazdasági és Jogi, 1963. 29. 
tisztviselőket az összes választásra jogosult lakos választotta, amelynek lebonyolítását szintén a szolgabíró koordinálta (időpontjának kitűzése, a választás kihirdetése és vezetése, a rend fenntartása). A szolgabírónak a község törvényes müködése miatt különösen jelentős községjegyzői és körjegyzői tisztség betöltése kapcsán további jogosultságai voltak, ugyanis ezen állomásokra a nyilvános pályázat kiírása és annak kihirdetése szintén a szolgabíró feladata volt. A körjegyzök választása esetén szintén a szolgabíró elnökölt a szövetkezett községek képviselőinek a körjegyzőség székhelyén tartandó ülésén. A körjegyzőséget fenntartó települések esetén a rendeleteket a szolgabíró a körjegyzőnek küldte meg, aki azt a község bírájával hajtotta végre. Ennek értelmében érthető, hogy az állami közigazgatás közvetítésében helyi szinten döntő szerepet betöltő községjegyzői és körjegyzői pozíciók tekintetében különösen erős hatásköröket rendelt a törvény a szolgabíróhoz.

A községi törvény a községi elöljárók fegyelmi felelösségéről is rendelkezett, ${ }^{36}$ amely szerint felettük a felügyelet és ellenőrzés jogát a képviselő-testület gyakorolhatta. ${ }^{37} \mathrm{~A}$ felelősségre vonásukra tiszti kereset keretében kerülhetett sor, amelyet vizsgálatnak kellett megelőznie. Kis- és nagyközség esetében a község belügyeit érintő kötelességszegések esetén a képviselő-testület rendelhette ezt el. Az állam érdekeinek sérelme okán viszont a szolgabíróhoz tartozott e jogosultság. Ilyen sérelem abban az esetben volt megállapítható, ha a községi elöljáró törvény vagy a törvényhatóság által irányába közvetített rendelet végrehajtását mulasztja el, vagy a törvényhatóság, illetve a kormány által még helyben nem hagyott, vagy megváltoztatott olyan határozatot vagy szabályrendeletet hajtott végre, amely még felsőbb jóváhagyásra várt. A szolgabíró által elrendelt vizsgálatot az általa megbízott személy folytatta le, ${ }^{38}$ amelyről a képviselő-testületet azonnal értesíteni kellett. A vizsgálat elrendelése esetén a szolgabíró felfüggeszthette a vétkes hivatalnokot, és helyettesítéséről intézkedhetett. ${ }^{39}$ A szolgabíró szükség esetén saját közegeivel a rendelet elmulasztott végrehajtását pótolhatta, amelynek következtében a föispán kivételes jogköréhez hasonló jogosultság illette meg őt a községekben. ${ }^{40}$ A vizsgálat eredményének függvényében a szolgabíró jogosult volt a tiszti keresetet megindítani a kis- és nagyközségek esetében, amelynek lefolytatása a község ügyészének vagy a szolgabíró megbízottjának kötelessége volt. A tiszti keresetet az illetékes magyar királyi törvényszék bírálta el. Ha a hivatalnok cselekménye nem minősült büncselekménynek, akkor dorgálással, pénzbírsággal vagy hivatalvesztéssel sújthatták.

36 Kérészy Zoltán: Községi közigazgatásunk alaptörvényének (1871:XVIII. t.-c.) előzményei. In Eckhart Ferenc - Degré Alajos: Emlékkönyv Dr. Viski Illés József ny. r. egyetemi tanár tanári müködésének negyvenedik évfordulójára. Budapest, Stephaneum, 1942. 247-300. 294.

37 Sarlós Béla: Közigazgatás és hatalompolitika a dualizmus rendszerében. Budapest, Akadémiai Kiadó, 1976. 102.

38 Csizmadia Andor: A magyar közigazgatás fejlödése a XVIII. századtól a tanácsrendszer létrejöttéig. Budapest, Akadémiai Kiadó, 1976. 132-133.

39 Az 1886:XXI. tc. felelősségi szabályozása is hasonló szakaszokból épült fel, így jól szemlélteti az eljárás lefolyását: Sallai Balázs: A közszolgálati fegyelmi felelősség kezdetei a polgári kori Magyarországon. Régiókutatás Szemle, 5. (2020), 1. 59-66. 62-64.

40 Stipta István: A főispáni hatáskör törvényi szabályozása (1870,1886). In Máthé Gábor - Zlinszky János: Degré Alajos emlékkönyv. Budapest, Unió, 1995. 299-312. 301. 
A járást vezető tisztviselö emellett a törvényhatóság nevében átvizsgálta a községek által elfogadott költségvetéseket, és a hiányok pótlására is felhívta a községeket, mielött a törvényhatósági bizottság elé kerültek volna. ${ }^{41}$ Ezek jóváhagyását a törvényhatóság csak akkor tagadhatta meg, ha az a törvényben meghatározott feltételeknek nem felelt meg, vagy a kiadásokat községi adóból fedezték, vagy, ha valamely adófizető a költségvetéssel szemben panasszal élt. A községnek ebben az esetben a szolgabíró útmutatásainak figyelembevételével kellett új költségvetést készítenie.

A járást vezető tisztviselők tehát a kis- és nagyközségek működésében hasonló szerepkört töltöttek be, mint a föispán és a belügyminisztérium a törvényhatóságokéban. Ebben az esetben is megfigyelhető az a dualizmus államszervezetéből következő jelenség, hogy a törvényhatóság nem ruházott át több jogot a községekre, mint amivel maga is rendelkezett. ${ }^{42}$ A rendi korszakban az alsófokú közigazgatási teendőket a szolgabíró a községek közremüködésével a földesúr támogatása mellett végezte. ${ }^{43}$ A jogegyenlőség megteremtésével 1848-ban a községek feletti földesúri hatalom megszűnt, így szükségesnek tartották, hogy a szolgabíró továbbra is segítse a községek müködtetését.

A községekkel kapcsolatos kötelességek a legtöbb vármegye hatásköri szabályzatában megjelent a szolgabírák kapcsán. ${ }^{44}$ A legrészletesebben e hatásköröket Fogaras vidék fejtette ki:

„[A] szolgabíró felügyel a hatosága alatt állo községekre, vezeti azok szervezését, képviseleti tagjai 's hivatalnokai megválasztatását's a megválasztott hivatalnokokat a törvény által kiszabott időre, megerősíti, felügyel továbbá a törvény korlátai közt a községek közigazgatása, közrendészete, gazdászata, törvénykezése és az adó behajtására; a hanyag és rendeleteket megszegő községi hivatalnokokat felfüggeszti állomásukból elmozditja ’s a végleges határozat hozataláig mások által helyettesiti." ${ }^{\text {45 }}$

A községi törvény csupán azt szabályozta, hogy a kormányrendeletek végrehajtásáért a kis- és nagyközségekben a bírák és a községjegyzők lesznek felelősek. Fogaras vidék ehhez hozzátette, hogy a szolgabíró felügyeli az állami közigazgatás érvényesülését a községekben, így ellenőrizve a tisztviselők munkáját. ${ }^{46} \mathrm{Ez}$ logikus következménye volt annak, hogy a szolgabírák voltak jogosultak a községi elöljárósággal szembeni felelősségrevonási eljárás megindítására.

$41 \quad$ MNL BM K150 118. 22592/1871.-Bereg vármegye; 233. 28643/1871.-Moson vármegye.

42 Stipta István: Törekvések a vármegyék polgári átalakítására. Budapest, Osiris, 1995. 132-133.

43 Dobszay Tamás: „A falu jegyzője” Az alsófokú igazgatás személyi feltételeinek kérdése a rendiség utolsó évtizedeiben. Századok, 149. (2015), 5. 1055-1067. 1055-1056.

44 MNL BM K150 117.21800/1871.-Fogaras vidék; 118. 22592/1871.-Bereg vármegye; 32032/1871.-Gömör és KisHont vármegye; 23891/1871.-Hunyad vármegye; 22187/1871.-Közép-Szolnok vármegye;22336/1871.-Veszprém vármegye; 233. 28463/1873.-Moson vármegye.

45 MNL BM K150 117.21800/1871.

46 MNL BM K150 21800/1871. 


\section{A SZOLGABÍRÓ SZEREPE AZ ADÓK BESZEDÉSÉBEN}

A kiegyezést követően került sor a modern magyar adórendszer kiépítésére is. Az 1868: XXI. tc. rendelkezett a közadókkal kapcsolatos eljárásokról. Az adók kivetésében az adóhivatalok mellett a törvényhatóságok és a községi elöljárók is részt vettek. Az egyénekre lebontott összeget föszabály szerint önkéntesen kellett megfizetnie az adózónak a községi adóhivatal, az adószedők vagy a községi elöljárók számára. A szolgabírák a törvény alapján az adóhátralékok behajtásában vettek részt, amelyet az adóhivatalok által megküldött kimutatások alapján végeztek el. ${ }^{47}$ Elöször a községi elöljárók segítségével megintették a hátralékos adókötelezetteket adófizetési kötelezettségük önkéntes teljesítése céljából. A pénzügyi tisztviselő a végrehajtást a szolgabíró közreműködésével végezte, aki a törvényhatóságot képviselte az eljárás során. Emellett a lefoglalt vagyontárgyak árverésének kihirdetése is a szolgabíró kötelessége volt.

Az októberi diplomát követően az adóigazgatási teendőket leválasztották a vármegyékröl, így jelentős változás hozott, hogy a kiegyezést követően a kormányzat ismételten bevonta a törvényhatóságokat az adózással kapcsolatos eljárásba. ${ }^{8}$ Már az 1867. május 23-án kelt pénzügyminiszteri rendelet felhívta a törvényhatóságokat, hogy a tisztviselők támogassák a magyar királyi pénzügyi felügyelőségeket munkájukban. ${ }^{49} \mathrm{~A}$ minisztérium a vármegyéktől a járásbeli tisztviselők magyar királyi adóhivataloknak nyújtandó segítségre való utasítását kérte. ${ }^{50} \mathrm{Az}$ 1868: XXI. tc. által vázolt szolgabírói szerepvállalás az adók behajtásában a vármegyék hatásköri szabályzataiban is megjelent. ${ }^{51}$ Doboka vármegye és Fogaras vidék az ezzel kapcsolatos hatásköröket akképp bővítette, hogy járási tisztviselői az adók összeírásában is részt vettek, valamint felügyelték az adószedők és a községi elöljárók munkáját, amelyről évnegyedenként jelentést tettek az alispánnak (Doboka vármegyében az alkapitánynak). Az évnegyedenkénti időtartam meghatározására amiatt került sor, mert az évi adót négy egyenlő részletben kellett megfizetni. Doboka, Felső-Fehér és Közép-Szolnok vármegye pedig az adó mérséklésére elemi csapások miatt beadott kérelem esetén a helyszíni szemlét utalta a szolgabírákhoz. ${ }^{52}$ A községi adókat is az országos adókkal megegyezően kellett beszedni, így Veszprém vármegye beemelte ezt

\footnotetext{
47 Boncz (1876) i. m. 128 e).

48 Szita János: Az adóigazgatás szervei a dualizmus első felében. In Ádám Antal - Benedek Ferenc - Szita János (szerk.): Jogtörténeti tanulmányok. Emlékkönyv Csizmadia Andor hetvenedik születésnapjára. Pécs, PTE Államés Jogtudományi Kar, 1980. 385-394. 385-388.

49 Stipta István: A pénzügyi közigazgatás szervezete Magyarországon 1849 és 1883 között. Miskolci Jogi Szemle, 8. (2013), 1. 18-34. 22-23.

50 58. A m. k. pénzügy ministeriumnak 1867. május 23-án kelt rendelete Magyarország valamennyi törvényhatóságához az adóbehajtás kérdésében. 146.

51 MNL BM K150 117.21272/1871.-Doboka vármegye; 22026/1871.-Felső-Fehér vármegye; 21800/1871.-Fogaras vidék; 118. 22592/1871.-Bereg vármegye; 32032/1871.-Gömör és Kis-Hont vármegye; 22187/1871.-KözépSzolnok vármegye; 22336/1871.-Veszprém vármegye; 233. 28463/1873.-Moson vármegye.

52 MNL BM K150 117. 21272/1871.; 22026/1871.; 118. 22187/1871.-Közép-Szolnok vármegye.
} 
is a szolgabírák hatáskörébe. Külön megjelölték, hogy e háziadóból fedezték a községek a tanítók és a lelkészek fizetéseit. ${ }^{53}$

\section{A KÖZBIZTONSÁG FENNTARTÁSA A JÁRÁSOKBAN}

A mezei rendőrségről szóló 1840: IX. tc. a szolgabírák hatáskörébe utalta a különböző mezőgazdasággal és iparral kapcsolatos településen kívüli károkozásokat, amelyek feletti felügyelet és bíráskodás megillette. ${ }^{54}$ Ezekben az ügyekben elsősorban $12 \mathrm{Ft}$ alatti kártétel esetén a községi elöljáróság bíráskodott, ha ezt elmulasztották, akkor a járást vezető tisztviselők jártak el. Emellett a szolgabírákhoz lehetett fellebbezni, valamint a nemesek ügyeiben kizárólag ők járhattak el. ${ }^{55} \mathrm{Az}$ áprilisi törvények azonban kimondták a törvény előtti egyenlőséget, míg az 1869: IV. tc. elválasztotta a közigazgatást és az igazságszolgáltatást. Emiatt több kétség is felmerült a törvény alkalmazása kapcsán. ${ }^{56}$

Bereg, valamint Gömör és Kis-Hont vármegye a mezei rendőrségi ügyekben való eljárást úgy hagyta meg a szolgabírák hatáskörében, hogyha a cselekmény bünvádi eljárásra vagy kártérítésre nem jelent jogalapot, és így nem a rendes bírósághoz tartozik. ${ }^{57}$ Bereg vármegye és Csongrád vármegye azt kérelmezte az igazságügyminisztériumnál, hogy ezekben az ügyekben továbbra is a közigazgatási tisztviselők járhassanak el. ${ }^{58}$ Veszprém és Moson vármegye szintén azokat a mezei rendőrségi ügyeket hagyta meg a szolgabíráknál, amelyek nem a törvénykezési szerveket illették. ${ }^{59}$ Moson vármegye kiemelte, hogy csupán fegyelmi vagy bírságolási tevékenységet végezhetnek a szolgabírák. Emellett megkísérelhettek egyezséget létrehozni a felek között, ha ez sikertelen, akkor rendes bírósághoz kellett őket utasítani. Felső-Fehér vármegye pedig úgy határozott, hogy

53 MNL BM K150 118. 22336/1871.

54 Bató Szilvia: „A járásbeli tisztség által megítélt bünügyek”. A szolgabírói szék büntető jellegű bíráskodása a Békési járásban (1843-1847). In Homoki-Nagy Mária (szerk.): Mezővárosaink jogélete a 18-19. században. Szeged, Pólay Elemér Alapítvány, 2010. 19-47. 28.

55 Zsoldos Ignác: A’ mezei rendörség’ föbb szabályai. Az 1840:IX. törvényczikkely’ nyomán. Pápa, Református Főiskola, 1842. 17-20.

56 Máthé Gábor: A magyar burzsoá igazságszolgáltatási szervezet kialakulása, 1867-1875. Budapest, Akadémiai Kiadó, 1982. 39-40.; Pétervári Máté: Az igazságszolgáltatás és közigazgatás elválasztása járási szinten. Acta Universitatis Szegediensis: Forum: Acta Juridica et Politica, 8. (2018), 1. 241-253. 243-246.; Szabó István: A bírói normakontroll bevezetése az 1869. IV. törvénycikkben. In Homoki-Nagy Mária: Konferencia a bírói hatalomról és az állampolgárságról. Szeged, Szegedi Egyetemi - Juhász Gyula Felsőoktatási, 2011. 175-184. 175.; Papp László: Különbíróságok szerepe és rendeltetése a modern igazságszolgáltatási rendszerekben. Acta Universitatis Szegediensis: Forum: Acta Juridica et Politica, 7. (2017), 1. 69-81. 69-70.

57 MNL BM K150 118. 22592/1871.; 32032/1871.

58 „A mezei és hegy rendőrség fontosságát kellő figyelemre méltatva, az alválasztmány szükségét látja, 's inditványba hozza, hogy irjon fel a megye az igazságügyministerhez miként terjesszen az országgyülés elé törvényjavaslatot arról, hogy a mezei rendörségi ügyek a mostani czélszerütlen felosztás megváltoztatása mellett általában tehát azok feletti biráskodás is a szolgabirák hatásköréhez utasittassanak." -MNL BM K150 118. 22592/1871.-Bereg vármegye; 117. 21068/1871.-Csongrád vármegye.

59 MNL BM K150 118. 22336/1871.; 233. 28463/1873.-Moson vármegye. 
a szolgabíró köteles a mezei rendőri szabályok megtartása felett őrködni, és az esetleges kártételeket kinyomozni. A járást vezető tisztviselő e törvényhatóságban csak a bizonyítékok összegyűjtésében, valamint a vizsgálóbíró és a szakértő orvos értesítésében vett részt. A büntető bíróság ügyeiben a tanúvallomások felvételében sem működhetett közre. ${ }^{60}$ Doboka vármegye viszont fenntartotta azt, hogy a szolgabírák mindaddig teljeskörüen eljárhatnak a mezei rendőrségi ügyekben, amíg kormányrendelet vagy törvény másképpen nem rendelkezik. ${ }^{61}$

Emellett a közbiztonság megőrzését is feladatukként határozták meg a vármegyék, ${ }^{62}$ így a mezei rendőrségi ügyeken kívül a közrendőri kihágások esetén is eljártak. ${ }^{63}$ Több vármegye a szolgabírák számára a közbiztonsági hatásköreik megkönnyítése céljából szolgaszemélyzetet is biztosított. A hasonló hatáskörű segédszemélyzet tagjait különböző elnevezésekkel illették a vármegyék. Bars, Csongrád, Hont és Bereg vármegyében egy-egy tiszti hajdú segítette a szolgabírák munkáját. ${ }^{64}$ Zala vármegye, valamint Gömör és KisHont vármegye egy-egy csendbiztost rendelt a járás élén álló tisztviselői mellé. ${ }^{65}$ Fejér vármegye és Kővár vidék úgy vélte, hogy egy csendbiztos két járás teendőit is megfelelöen képes lesz ellátni. ${ }^{66}$ Kővár vidék emellett járásonként még egy-egy tiszti hajdút is alkalmazott. ${ }^{67}$ Békés vármegye járásonként egy csendbiztos, egy csendlegény és egy tiszti hajdú szolgálatba állítását vélte szükségesnek. ${ }^{68}$ Veszprém vármegye minden járásában a szolgabírák munkáját tiszti katonák hivatalba állításával segítette. ${ }^{69}$ Felső-Fehér vármegye pedig arra kötelezte szolgabíráit, hogy szolgabírói pandúrokat vegyenek igénybe feladataik ellátása során. ${ }^{70}$

E vármegyei személyzet hatásköréről, munkájáról a vármegyei tervezetek kevés információt tartalmaztak. Gömör és Kis-Hont vármegye akképpen szabályozta csendbiztosainak hatáskörét, hogy „a csendbiztos és pandúrjai a szolgabirák rendelkezései alatt

60 MNL BM K150 117. 22026/1871.

61 MNL BM K150 117. 21272/1871.

62 MNL BM K150 118. 22592/1871.-Bereg vármegye; 22187/1871.-Közép-Szolnok vármegye; 30937/1871. Moson vármegye; 22336/1871.-Veszprém vármegye; „Az állam hatalom, s hatoságainak tekintélyét, ugy a törvényes állami szervezet biztonságáért kötelessége felügyelni; járásában folytonos gondot forditván a vagyon s. személy biztonság állandó fenntartására - illetőleg biztosítására; melynek eshető meg zavarása esetén rögtön jelentést tész az alispánnak, s kiszálva ahely színére a rendelkezése alatti tőrvényes eszközökkel köteles saját felelőségére, fel zavart rendet, nyugalmat helyre állítani.” 117. 21272/1871.-Doboka vármegye; 22026/1871.-FelsőFehér vármegye; 20826/1871.-Sáros vármegye.

63 MNL BM K150 117. 21272/1871.-Doboka vármegye; 20826/1871.-Sáros vármegye; 118. 23891/1871.-Hunyad vármegye.

64 MNL BM K150 117. 21799/1871.; 27282/1871.; 118. 28726/1871.; 22592/1871.

65 MNL BM K150 117. 21798/1871.; 118. 32051/1871.; 22499/1871.

66 MNL BM K150 117. 17808/1871.; 118. 22499/1871.

67 MNL BM K150 118. 22499/1871.

$68 \quad$ MNL BM K150 117.31913/1871.

69 MNL BM K150 118. 22336/1871.

70 „Hivatalos végre hajtó kőzegűl a szolgabíro kőteles saját kőlcségén egy illően kiruházott pandurt tartani, kinek részére a fegyverzetet a tőrvényhatoság szolgáltatja.” MNL BM K150 117. 22026/1871. 
állanak". ${ }^{71}$ Ezáltal már tekintélyes létszámú segédszemélyzet állt a szolgabíró rendelkezésére a vármegyében, mivel hat szolgabírói pandúr tartozott egy járáshoz a csendbiztos mellett. ${ }^{72}$ Kővár vidék ezzel szemben arra hivatkozva, hogy „a szolgabírák is kötelesek a csendre és rendre felügyelni” két szolgabírói járásra csupán egy csendbiztos alkalmazását rendelte el. ${ }^{73} \mathrm{Ha}$ összevetjük a két törvényhatóság szabályozását, akkor az észlelhető, hogy Kővár vidék esetében már nem annyira egyértelmü, hogy a csendbiztosok munkájuk során a szolgabírónak alárendelten jártak el. Ez azzal hozható összefüggésbe, hogy Erdélyben a kiegyezést megelőzően a császári és királyi csendőrség miatt nem alakult ki törvényhatósági közbiztonsági személyzet, ${ }^{74}$ így Kővár vidék újonnan hozta létre a csendbiztosi tisztséget. A csendőrség sorsáról a köztörvényhatósági törvény megszületésekor még nem született döntés. Ennek megfelelően megfigyelhető, hogy az erdélyi vármegyék kisebb létszámban tették közigazgatási szervezetük részévé a közbiztonsági közegeket. ${ }^{75}$

A járási tisztviselők a rendőri kihágásokat akadályozták meg és azok elkövetőit büntették meg, a bünelkövetők után nyomoztak és körözték őket, sikeres elfogás esetén pedig az illetékes bíróság elé kísérték. A szolgabírák közbiztonsági feladatai ezenkívül a következők voltak: a járásukban a vásárok felügyelete, az idegen koldusok és kóborlók visszakísértetése a községi illetőségüknek megfelelő településre és az igazolási jegyek és útlevelek láttamozása. ${ }^{76}$ Doboka vármegye emellett a szolgabíró számára jogot biztosított arra, hogy olyan gyüléseket vagy mozgalmakat betiltson, amelyek a tulajdon jogtalan megtámadására vagy a fennálló alkotmányos rend erőszakos megváltoztatására irányulnak. ${ }^{77}$ Fogaras vidéken a községi elöljáróságok rendőri ügyekben hozott határozatai elleni fellebbezéseket is elbírálta ${ }^{78}$ Csongrád vármegye a közbiztonság fenntartására irányuló feladatok közül a pásztorok névjegyzékének a csendbiztosok segítségével történő összeírását emelte ki, akiknek felelősségre vonása szintén az ő kötelezettségük volt. ${ }^{79}$ Doboka, Közép-Szolnok, Hunyad és Moson vármegye pedig a községi erdőkben az erdészeti szabályok feletti felügyeletet és a kihágások felderítését is a szolgabírákhoz utalta. ${ }^{80} \mathrm{~A}$ legrészletesebb szabályzatot készítő Doboka vármegye szintén ebbe a körbe sorolta a jogosulatlan fegyverhasználat és a mészárszékek, kocsmák mértékeinek felügyeletét, valamint azt, hogy a tartózkodásuk célját és létfenntartásuk módját igazolni nem tudó idegeneket, illetve a kuruzslókat és „a népnyugalmat megzavaró ámítókat” kitoloncoltathatta a szolgabíró. A közbiztonság megőrzése céljából kellett a járásukban a vallásszabadságot is biztosítaniuk. ${ }^{81}$

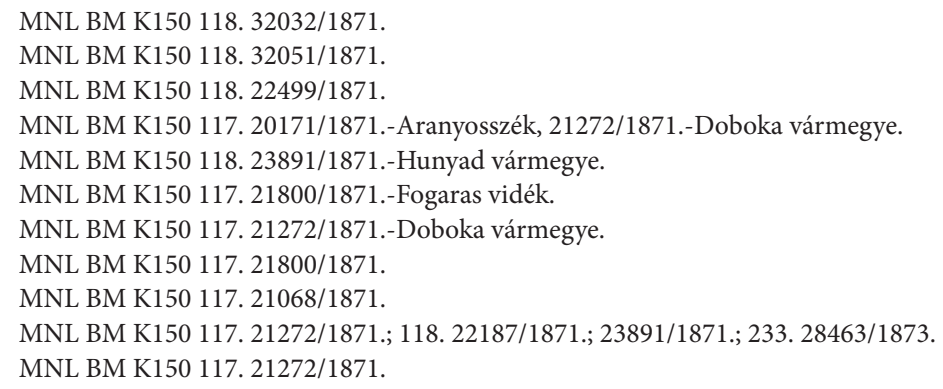


A mezei rendőrségi ügyeknél ritkábban előforduló, de ugyanúgy a közigazgatás és az igazságszolgáltatás elválasztása miatt problémás kérdés volt a vásárbíráskodás, amelyet a polgári törvénykezési rendtartás tárgyában hozott 1868: LIV. tc. a szolgabírák és az esküdtek törvénykezési fóruma elé utalt a nagy- és kisközségek esetében. Az esküdti pozíció azonban megszünt az 1870: XLII. tc. hatálybalépésével. ${ }^{82}$ Felső-Fehér és Doboka vármegye így hatásköri szabályzatában a szolgabírák feladatai között meghagyta, hogy egyesbíróként a vásári ügyekben eljárjanak az 1868: LIV. tc. értelmében. ${ }^{83} \mathrm{~A}$ szolgabírák az országos és heti vásárok alatt az azzal összefüggő adóssági és adásvételi szerződésekkel kapcsolatos jogvitákban ítélkeztek e jogkörükben. Szintén a közigazgatás és az igazságszolgáltatás elválasztásával nehezen összeegyeztethető, hogy Doboka vármegye a becsületsértési ügyek elbírálását első fokon a szolgabírákhoz utalta. ${ }^{84}$

\section{A NEM ORSZÁGOS JELLEGGEL ELŐFORDULÓ SZOLGABÍRÓI HATÁSKÖRÖK}

A községekben előforduló iparügyekben az elsőfokú eljárás lefolytatása ${ }^{85}$ és az iparjegyek kiállítása szintén a szolgabírák feladatai közé tartoztak a törvény hatálybalépését követően. ${ }^{86}$ Fogaras vidék és Sáros vármegye a neoabszolutizmus időszakából származó 1859. december 20-án kelt 227. számú nyílt parancsból származtatta a szabad ipar gyakorlására az engedélyek kiadásának jogosultságát ${ }^{87}$ amely alapján nyilvántartást vezettek a járásukban található kereskedőkről, gyárosokról és kézművesekrôll. ${ }^{88}$ Doboka vármegye emellett a szolgabírák számára biztosította a királyi kisebb haszonvételek engedélyezését. ${ }^{89}$

Az árva- és gyámhatóság gyakorlását az 1870: XLII. tc. megtartotta a törvényhatóságoknál, amely munkálatok elvégzésére az árvaszéket rendelték. Az árvaszék egy elnökből, két ülnökből, a tiszti ügyészből, a számvevőből, egy jegyzőből és a szavazattal nem rendelkező közgyámból állt. A vármegyék jelentős részében így az árvaszéki végzéseket

82 Pétervári Máté: A szolgabírói hivatal az 1870. évi XLII. törvénycikk alapján. Pro Publico Bono - Magyar Közigazgatás, (2018), 3. 56-77. 60-61.

$83 \quad$ MNL BM K150 117. 21272/1871.; 22026/1871.

$84 \quad$ MNL BM K150 117. 21272/1871.

85 Boncz (1876) i. m. 128 e).

86 MNL BM K150 117.21272/1871.-Doboka vármegye; 22026/1871.-Felső-Fehér vármegye; 21800/1871.-Fogaras vidék; 118. 22592/1871.-Bereg vármegye; 32032/1871.-Gömör és Kis-Hont vármegye; 22187/1871.-KözépSzolnok vármegye; 22336/1871.-Veszprém vármegye; 233. 28463/1873.-Moson vármegye.

87 227. Kaiserliches Patent vom 20. December 1859, womit eine Gewerbe-Ordnung für den ganzen Umfang des Reiches, mit Ausnahme des venetianischen Verwaltungsgebietes und der Militärgrenze, erlassen, und vom 1. Mai 1860 angefangen in Wirksamkeit gesetzt wird. Reichs-Gesetz-Blatt für das Kaiserthum Oesterreich. Jahrgang 1859, 65. sz. Ausgegeben und versendet am 27. December 1859. 619-650.

88 MNL BM K150 117. 21800/1871.; 20826/1871.

89 MNL BM K150 117. 21272/1871. 
a szolgabírák hajtották végre. ${ }^{90}$ Több törvényhatóság a járási közgyámi tisztség rendszeresítését mellőzte, így Kővár vidéken és Moson vármegyében a szolgabíró, míg Aranyosszék esetében a dulló látta el e hivatalnok feladatait. ${ }^{91} \mathrm{Ez}$ a megoldás a neoabszolutizmus korának szabályozásával is összhangban állt. ${ }^{92}$

A szolgabírák kötelessége volt számos törvényhatóságban a közjólét érdekében tevékenykedni. ${ }^{93}$ A népiskolai közoktatás tárgyában elfogadott 1868: XXXVIII. tc. értelmében a tanköteles diákokat az iskolába járástól távoltartó szülővel szemben bírság volt kiszabható, az ezzel kapcsolatos fellebbezéseket szintén a szolgabíró bírálta el. ${ }^{94}$ KözépSzolnok vármegye az iskolákkal kapcsolatban szélesebb hatáskört biztosított, mivel a községi és a felekezeti iskolák, valamint a felnőttoktatás fenntartására felügyelt a szolgabíró, aki erről jelentést tett az alispánnak. ${ }^{95}$ Doboka vármegyében ezenkívül a szolgabíró felügyelte a munkatehetetlen, segélyezésre szorult szegényekkel szembeni gondoskodást. Ha erre nem volt képes a település, akkor jelentést tett az alispánhoz. ${ }^{96}$ Felső-Fehér vármegye esetében a kereskedő vagy iparos és segédei, illetve a gazda és cselédei közötti jogviták kapcsán felmerült panaszokat a járást vezető tisztviselők a vármegye 1868. évi cselédrendtartása szerint intézték el. ${ }^{97}$ Doboka és Moson vármegye szintén a szolgabírák feladatául szabta, hogy az aratókkal, cséplőkkel, egyéb munkásokkal, illetve a cselédekkel kötött szerződések körüli jogvitákat rendezzék. ${ }^{98}$

A szolgabírák felügyeltek a közegészségügyi és állategészségügyi viszonyokra is, így éhínség, ragályos megbetegedések vagy marhavész esetén a megfelelő intézkedéseket kellett megtenniük. Ezt követően pedig a járási orvost vagy az állatorvost értesítették. ${ }^{99}$ A beteg marhák elkülönítése nem csupán a hatásköri szabályzatok, hanem a mezei rendőrségi törvény alapján is kötelessége volt a járást vezető tisztviselőknek.

Erdély területén problémát jelentett a neoabszolutizmus rendeleteinek hatályban tartása a kiegyezést követően, ugyanis több törvényhatóság ezek alapján kihágási ügyekben megállapította szolgabíráinak hatáskörét. Az osztrák büntető törvénykönyv alapján kisebb jelentőségü büntetőügyekben, ${ }^{100}$ az 1852. évi erdőtörvény alapján kihá-

90 MNL BM K150 117. 20171/1871.-Aranyosszék; 20826/1871.-Sáros vármegye; 118. 22592/1871.-Bereg vármegye; 32032/1871.-Gömör és Kis-Hont vármegye; 22499/1871.-Kővár vidék; 22336/1871.-Veszprém vármegye; 233. 28463/1873.-Moson vármegye.

91 A dulló elnevezést alkalmazta Aranyosszék törvényhatósága a járást vezető tisztviselőire.

92 Homoki-Nagy Mária: A magyar gyámsági jog a neoabszolutizmus korában. Acta Universitatis Szegediensis: Forum: Acta Juridica et Politica, 9. (2019), 1. 45-55. 49-50.

93 MNL BM K150 117. 21272/1871.-Doboka vármegye; 21800/1871.-Fogaras vidék.

94 MNL BM K150 117.21272/1871.-Doboka vármegye; 22026/1871.-Felső-Fehér vármegye; 21800/1871.-Fogaras vidék.

95 MNL BM K150 118. 22187/1871.-Közép-Szolnok vármegye.

96 MNL BM K150 117. 21272/1871.

$97 \quad$ MNL BM K150 117. 22026/1871.

98 MNL BM K150 117. 21272/1871.; 118. 30937/1871.

99 MNL BM K150 117. 21272/1871.-Doboka vármegye; 22026/1871.-Felső-Fehér vármegye; 118. 22187/1871.-Közép-Szolnok vármegye; 22336/1871.-Veszprém vármegye.

100 88. Kaiserliche Verordnung vom 20. Juni 1858, wirksam für alle Kronländer, mit Ausnahme des lombardischvenetianischen Königreiches und der Militärgrenze, wodurch die Gerichtsbarkeit über mehrere Uebertretungen 
gási ügyekben ${ }^{101}$ és mezei rendőrségi ügyekben járhattak el a járást vezető tisztviselők bizonyos vármegyékben. ${ }^{102}$

Aranyosszék, Fogaras vidék és Felső-Fehér vármegye egy 1869. évi belügyminiszteri rendelet folytán a jobbágyfelszabadításból hátramaradt vitás kérdések, így elsősorban a közös tulajdonú legelők és erdők, valamint a közbirtokosságok rendezését a járást vezető tisztviselőkhöz utalta. ${ }^{103} \mathrm{Az}$ 1858. évi építési rendtartás értelmében az építkezések helyszíni vizsgálata és azok engedélyezése, valamint a községi középítkezéseknek és az iparüzletek építésének a véleményezése is a szolgabírákhoz tartozott. ${ }^{104}$

Sáros vármegye hatásköri szabályzatában egyedülálló feladat jelent meg, mivel ez alapján a szolgabírák eljártak a járásuk területén felmerülő határmegújítási (reambulatio metarum) ügyekben. ${ }^{105} \mathrm{~A}$ legkülönlegesebb feladatot azonban Közép-Szolnok vármegye határozta meg hatásköri szabályzatában, a szolgabíráknak ugyanis az országos statisztikai hivatalok hiányában minden év utolsó közgyülésén jelentést kellett tenniük a járásuk területén termett gabona és takarmány mennyiségéről, valamint a régészeti, történelmi és néprajzi tekintetben kiemelkedő leletekről és eseményekről. ${ }^{106}$

Emellett megjelentek az általános jellegű meghatározások is, így a szolgabírák feladata volt járási szinten a „közgyűlési határozatok és alispáni rendeletek végrehajtása” ${ }^{107}$ Az alispáni intézkedésekkel szemben felmerült nehézségek vagy akadályok esetén pedig

des allgemeinen Strafgesetzes den politischen Behörden zugewiesen, und das hierüber von diesen Behörden zu beobachtende Strafverfahren geregelt wird. Reichs-Gesetz-Blatt für das Kaiserthum Oesterreich. Jahrgang 1858, 24. sz. Ausgegeben und versendet am 23. Juni 1858. 383-388.; MNL BM K150 117. 21272/1871.-Doboka vármegye; 22026/1871.-Felső-Fehér vármegye, 21800/1871.-Fogaras vidék.

101 250. Kaiserliches Patent von 3. December 1852, wirksam für die Kronländer Oesterreich unter und ob der Enns, Salzburg, Steiermark, Kärnthen, Krain, Görz, Gradiska, Istrien, Triest, Tirol und Vorarlberg, Böhmen, Mähren, Schlesien, Galizien, mit Krakau und die Bukowina, wodurch für diese Kronländer ein neues Forstgesetz erlassen, und vom 1. Jänner 1853 angefangen in Wirksamkeit gesetzt wird. Allgemeines ReichsGesetz und Regierungsblatt für das Kaiserthum Oesterreich. Jahrgang 1852, 72. sz. Ausgegeben und versendet am 14. December 1852. 1053-1080;; MNL BM K150 117. 21800/1871.-Fogaras vidék.

102 28. Verordnung der Ministerien des Innern und der Justiz vom 30. Jänner 1860, wirksam für alle Kronländer, mit Ausnahme des venetianischen Verwaltungsgebietes, des Königreiches Dalmatien und der Militärgrenze, betreffend die Bestellung eines beeideten Feldschutzpersonales und das Verfahren über Feldfrevel. ReichsGesetz-Blatt für das Kaiserthum Oesterreich. Jahrgang 1860, 6. sz. Ausgegeben und versendet am 2. Februar 1860. 59-66.; MNL BM K150 117. 21800/1871.-Fogaras vidék.

103 „Az 1869. Mártius hó 14-én 963. eln. szám alatt kelt Belügy ministeri rendelet folytán az urbéri ügyekben és az urbéri viszonyokból eredő a volt urbéresek és volt földesurak között felmerülő legeltetési és faizási joggyakorlatot illető ügyekben a tényleges állapot felett, vagy szintén a hátralékos szolgálmányokés a hátralékos malom taksák behajtása tárgyában, továbbá korcsmáltatási jog gyakorlata felett a volt urbéresek és regaletulajdonosok vagy ezen utobbiak között felmerült egyenetlenségek, nemkülönben korcsma arányositása és legelő szabályozásoknál felmerült vitás kérdésekben, melyekben eddig első hatóságilag az alkapitány működött, ezennel tehát a fennemlitett ügyek elintézése a szolgabirákra ruháztatik át.” MNL BM K150 117. 21272/1871.-Doboka vármegye; 21800/1871.-Fogaras vidék; 22026/1871.-Felső-Fehér vármegye; 20171/1871.-Aranyosszék; 118. 22187/1871.-Közép-Szolnok vármegye.

104 MNL BM K150 117. 22026/1871.-Felső-Fehér vármegye; 21800/1871.-Fogaras vidék

105 MNL BM K150 117. 20826/1871.-Sáros vármegye.

106 MNL BM K150 118. 22187/1871.

107 MNL BM K150 117. 21272/1871.-Doboka vármegye; 22026/1871.-Felső-Fehér vármegye; 118. 22592/1871. Bereg vármegye; 32032/1871.-Gömör és Kis-Hont vármegye; 233. 28463/1873.-Moson vármegye. 
aggályait fejezhette ki az alispán irányába a járást vezető tisztviselő. Ha az alispán fenntartotta azt, akkor a szolgabíró köteles volt végrehajtani, de ezért az alispán vállalta a felelősséget. ${ }^{108}$ A szolgabírák kézbesítették a megyében az iratokat. ${ }^{109}$ Felső-Fehér és Doboka vármegye részletesen megszabta ennek megvalósulását, miszerint az átvétel tényét aláírásával kellett igazolnia a címzettnek a kézbesítés idejének feltüntetése mellett. Írástudatlan címzett esetén pedig a kézbesítő tisztviselőnek az irat tartalmát is meg kellett magyaráznia. A szolgabírákat emellett kötelezték, hogy bizonyos időközönként (évnegyedenként) utazzák be a járásukhoz tartozó községeket. ${ }^{110}$ Felső-Fehér vármegye megszabta azt is, hogy ilyenkor köteles a községi pénztárakat megvizsgálni, az iskolákat meglátogatni, valamint a tüzoltó társulatok és tűzoltószerek müködéséről személyesen meggyőződni. Erről pedig az alispánnak jelentést kellett benyújtania. ${ }^{111}$

\section{A SZOLGABÍRÁK SZEREPE A TÖRVÉNYHATÓSÁGOK ÉLETÉBEN}

Az ismertetett szolgabírói hatáskörök alapján kijelenthető, hogy a járást vezető tisztviselők az alsó középszint általános hatáskörü közigazgatási szervei voltak, ${ }^{112}$ akik szoros egységben jártak el a közigazgatást vezető alispánnal. A legfontosabb hatásköreik megmaradtak a rendi korszakból, amelyeket egységesen szabályoztak a törvényhatóságok. Az e kérdésben meglévő egyetértést jól példázza, hogy Szentkirályi Móric a közigazgatás átszervezéséről 1867-ben megjelent munkájában szintén a községek feletti felügyeletet tartotta a szolgabírák legfontosabb feladatának, amelyben még szorosabb ellenőrzési jogköröket kívánt volna. Emellett szintén az adók behajtásában, a közmunkák lebonyolításában, az utak karbantartásában és a közegészségi állapotok feletti felügyeletben szánt szerepet a járási tisztviselőknek. ${ }^{113}$

A szolgabírák hatásköre azonban a törvénykezési feladatok elvesztése ellenére is igen tág maradt. Ez annak is volt köszönhető, hogy több törvényhatóság figyelmen kívül hagyta az első folyamodású bíróságok rendezéséről szóló 1871: XXXI. tc. 15. \$-át, miszerint a szolgabírák által ellátott törvénykezési teendők a járásbíróságokhoz kerülnek. Emiatt törvényellenesen a szolgabíráknál tartottak bizonyos bíráskodási jogköröket. Emellett a vármegyék hatásköri szabályozásánál is kitűnik az a probléma, hogy a kiegyezést követően, különösen Erdélyben, nem volt egyértelmü, hogy mely jogszabályok vannak hatályban.

108 MNL BM K150 117. 21272/1871.-Doboka vármegye.

109 MNL BM K150 117. 21272/1871.-Doboka vármegye; 22026/1871.-Felső-Fehér vármegye.

110 MNL BM K150 117. 21272/1871.-Doboka vármegye; 22026/1871.-Felső-Fehér vármegye; 118. 22592/1871.Bereg vármegye; 22187/1871.-Közép-Szolnok vármegye; 233. 28463/1873.-Moson vármegye.

111 MNL BM K150 117. 22026/1871.

112 „A szolgabiráknak a 61§-ban körülirt teendöin kivül hatáskörük alatt maradnak mind azon ügyek, melyeket eddig a törvény és szabályrendeletek a szolgabirói hatáskörhöz utasitottak, s melyek az ujabb törvények vagy illem szabályok által a törvénykezési bíróságokhoz vagy más hatóságokhoz nem utasittattak, vagy ezután utasittatni fognak.” MNL BM K150 117. 21068/1871.-Csongrád vármegye.

113 Szentkirályi Móricz: Eszmetöredékek a vármegyék rendezéséről. Pest, Budapesti Szemle, 1867. 64-65. 
A szolgabírák hatáskörét pedig ezenkívül parttalanná tette, hogy a vármegyék nem törekedtek a feladatkörök taxatív felsorolására, így egyértelmüen nem lehetett meghatározni a szolgabírák összes eljárási hatáskörét. E célt egyedül Doboka vármegye kívánta elérni. Több vármegye ezt külön hangsúlyozta azáltal, hogy a szolgabírák feladatait a szabályzaton túl a törvények, a szabályrendeletek, a törvényes szokás és a fennálló gyakorlat határozza meg. ${ }^{114}$ A szolgabíró továbbra is megmaradt a járás lakosságának „ügyes-bajos dolgainak ügyintézője”. ${ }^{115}$ Ennek fényében kijelenthető, hogy a szolgabírákra különösen igaz volt Bars vármegye alábbi jellemzése: „A közigazgatási tisztviselőnek, szakja természeténél fogva nem annyira a hivatalszoba emberének, de mindenütt jelenlevő, mindent megfigyelö állami közegnek kell lennie,- 's a legfontosabb, fárasztóbb közigazgatási functiokat teljesiteni. ${ }^{" 116}$

114 MNL BM K150 117. 21068/1871.-Csongrád vármegye; 22026/1871.-Felső-Fehér vármegye; 118. 32032/1871.Gömör és Kis-Hont vármegye; 22187/1871.-Közép-Szolnok vármegye; 233. 28463/1873.-Moson vármegye.

115 MNL BM K150 118. 22499/1871.-Kővár vidék.

116 MNL BM K150 117. 28287/1871. 


\section{FELHASZNÁLT IRODALOM}

1. Bató Szilvia: „A járásbeli tisztség által megítélt bünügyek”. A szolgabírói szék büntető jellegü bíráskodása a Békési járásban (1843-1847). In Homoki-Nagy Mária (szerk.): Mezövárosaink jogélete a 18-19. században. Szeged, Pólay Elemér Alapítvány, 2010. $19-47$.

2. Boncz Ferenc: A magyar közigazgatási törvénytudomány kézikönyve a törvényhozás legújabb állása szerint. I. kötet. Budapest, Athenaeum, 1876.

3. Csizmadia Andor: A magyar közigazgatás fejlődése a XVIII. századtól a tanácsrendszer létrejöttéig. Budapest, Akadémiai Kiadó, 1976.

4. Dobszay Tamás: „A falu jegyzője” Az alsófokú igazgatás személyi feltételeinek kérdése a rendiség utolsó évtizedeiben. Századok, 149. (2015), 5. 1055-1067.

5. Hencz Aurél: Területrendezési törekvések Magyarországon. Budapest, Közgazdasági és Jogi Könyvkiadó, 1973.

6. Homoki-Nagy Mária: A magyar gyámsági jog a neoabszolutizmus korában. Acta Universitatis Szegediensis: Forum: Acta Juridica et Politica, 9. (2019), 1. 45-55.

7. Kassay Adolf: A szolgabirák és megyei esküdtek hatásköre és teendői. Pest, Stolp Károly, 1865.

8. Kérészy Zoltán: Községi közigazgatásunk alaptörvényének (1871:XVIII. t.-c.) elözményei. In Eckhart Ferenc - Degré Alajos: Emlékkönyv Dr. Viski Illés József ny. r. egyetemi tanár tanári müködésének negyvenedik évfordulójára. Budapest, Stephaneum, 1942. 247-300.

9. Márkus Dezső: Ungarisches Verwaltungsrecht. Tübingen, Mohr, 1912.

10. Máthé Gábor: A magyar burzsoá igazságszolgáltatási szervezet kialakulása, 1867-1875. Budapest, Akadémiai Kiadó, 1982.

11. Máthé Gábor: Polgári kori közigazgatásunk történeti jellemzői. In Imre Miklós - Lamm Vanda - Máthé Gábor (szerk.): Közjogi tanulmányok Lörincz Lajos 70. születésnapja tiszteletére. Budapest, Aula, 2006. 262-267.

12. Megyeri-Pálffi Zoltán: A Hajdúböszörményi Járásbíróság megszervezésének és elhelyezésének története. In Megyeri-Pálffi Zoltán (szerk.): A jogszolgáltatás története Hajdúböszörményben. Debrecen, Debreceni Törvényszék, 2018. 59-77.

13. Nagy Iván (szerk.): Az 1869-dik évi april 20-dikára hirdetett országgyülés képviselöházának naplója. XV. k. Pest, Légrády Testvérek, 1871.

14. Papp László: Különbíróságok szerepe és rendeltetése a modern igazságszolgáltatási rendszerekben. Acta Universitatis Szegediensis: Forum: Acta Juridica et Politica, 7. (2017), 1. 69-81.

15. Pétervári Máté: Az igazságszolgáltatás és közigazgatás elválasztása járási szinten. Acta Universitatis Szegediensis: Forum: Acta Juridica et Politica, 8. (2018), 1. 241-253.

16. Pétervári Máté: A szolgabírói hivatal az 1870. évi XLII. törvénycikk alapján. Pro Publico Bono - Magyar Közigazgatás, (2018), 3. 56-77. 
17. Sallai Balázs: A közszolgálati fegyelmi felelősség kezdetei a polgári kori Magyarországon. Régiókutatás Szemle, 5. (2020), 1. 59-66. DOI: https://doi.org/10.30716/ RSZ/2020/1/5

18. Sarlós Béla: Közigazgatás és hatalompolitika a dualizmus rendszerében. Budapest, Akadémiai Kiadó, 1976.

19. Stipta István: Az első polgári kori vármegyetörvény (1848:XVI. tc). Acta Universitatis Szegediensis: Acta Juridica et Politica, 42. (1992), 5. 3-34.

20. Stipta István: Intézménytörténeti adalékok az 1870:XLII. tc. végrehajtásához. In Tóth Károly (szerk.): Emlékkönyv Dr. Cséka Ervin egyetemi tanár születésének 70. és oktatói munkásságának 25. évfordulójára. Szeged, JATE, 1992. 481-494.

21. Stipta István: A főispáni hatáskör törvényi szabályozása (1870, 1886). In Máthé Gábor - Zlinszky János: Degré Alajos emlékkönyv. Budapest, Unió, 1995. 299-312.

22. Stipta István: Törekvések a vármegyék polgári átalakítására. Budapest, Osiris, 1995.

23. Stipta István: A magyar birósági rendszer története. Debrecen, Multiplex Media Debrecen U. P., 1998.

24. Stipta István: A pénzügyi közigazgatás szervezete Magyarországon 1849 és 1883 között. Miskolci Jogi Szemle, 8. (2013), 1. 18-34.

25. Szabó István: A bírói normakontroll bevezetése az 1869. IV. törvénycikkben. In Homoki-Nagy Mária: Konferencia a bírói hatalomról és az állampolgárságról. Szeged, Szegedi Egyetemi - Juhász Gyula Felsőoktatási, 2011. 175-184.

26. Szentkirályi Móricz: Eszmetöredékek a vármegyék rendezéséröl. Pest, Budapesti Szemle, 1867.

27. Székely Tamás: A közigazgatás átalakításának programja. Modernizáció és nemzetállam-építés a dualizmus korában. In Csibi Norbert - Schwarczwölder Ádám (szerk.): Modernizácó és nemzetállam-építés. Haza és/vagy haladás dilemmája a dualizmus kori Magyarországon. Pécs, Kronosz, 2018. 165-180.

28. Szita János: Az adóigazgatás szervei a dualizmus első felében. In Ádám Antal - Benedek Ferenc - Szita János (szerk.): Jogtörténeti tanulmányok. Emlékkönyv Csizmadia Andor hetvenedik születésnapjára. Pécs, PTE Állam- és Jogtudományi Kar, 1980. 385-394.

29. Takács Imre: A járási tanácsok feladatai. Budapest, Közgazdasági és Jogi Könyvkiadó, 1963.

30. Varga Norbert: A főispáni tisztség bevezetése Debrecen és Szeged szabad királyi városokban a köztörvényhatósági törvény alapján. In Mezey Barna - Révész T. Mihály (szerk.): Ünnepi tanulmányok Máthé Gábor 65. születésnapja tiszteletére. Budapest, Gondolat, 2006. 606-623.

31. Varga Norbert: A virilizmus bevezetése és a cégek virilis jogának megítélése Szegeden. Jogtörténeti Szemle, 13. (2011), 1. 43-47.

32. Varga Norbert: A föispán és a városi közigazgatás reformja a polgári korban. Pro Publico Bono - Magyar Közigazgatás, (2018), 1. 180-199.

33. Zsoldos Ignác: A’ szolgabírói hivatal. Közrendtartási rész. Pápa, Református Főiskola, 1842. 
34. Zsoldos Ignác: A szolgabírói hivatal. Törvénykezési rész. Pápa, Református Főiskola, 1842.

35. Zsoldos Ignác: A’mezei rendörség’főbb szabályai. Az 1840:IX. törvényczikkely’ nyomán. Pápa, Református Főiskola, 1842.

\section{Jogi források}

1. 250. Kaiserliches Patent von 3. December 1852, wirksam für die Kronländer Oesterreich unter und ob der Enns, Salzburg, Steiermark, Kärnthen, Krain, Görz, Gradiska, Istrien, Triest, Tirol und Vorarlberg, Böhmen, Mähren, Schlesien, Galizien, mit Krakau und die Bukowina, wodurch für diese Kronländer ein neues Forstgesetz erlassen, und vom 1. Jänner 1853 angefangen in Wirksamkeit gesetzt wird. Allgemeines Reichs-Gesetz und Regierungsblatt für das Kaiserthum Oesterreich. Jahrgang 1852, 72. sz. Ausgegeben und versendet am 14. December 1852.

2. 88. Kaiserliche Verordnung vom 20. Juni 1858, wirksam für alle Kronländer, mit Ausnahme des lombardisch-venetianischen Königreiches und der Militärgrenze, wodurch die Gerichtsbarkeit über mehrere Uebertretungen des allgemeinen Strafgesetzes den politischen Behörden zugewiesen, und das hierüber von diesen Behörden zu beobachtende Strafverfahren geregelt wird. Reichs-Gesetz-Blatt für das Kaiserthum Oesterreich. Jahrgang 1858, 24. sz. Ausgegeben und versendet am 23. Juni 1858.

3. 227. Kaiserliches Patent vom 20. December 1859, womit eine Gewerbe-Ordnung für den ganzen Umfang des Reiches, mit Ausnahme des venetianischen Verwaltungsgebietes und der Militärgrenze, erlassen, und vom 1. Mai 1860 angefangen in Wirksamkeit gesetzt wird. Reichs-Gesetz-Blatt für das Kaiserthum Oesterreich. Jahrgang 1859, 65. sz. Ausgegeben und versendet am 27. December 1859.

4. 28. Verordnung der Ministerien des Innern und der Justiz vom 30. Jänner 1860, wirksam für alle Kronländer, mit Ausnahme des venetianischen Verwaltungsgebietes, des Königreiches Dalmatien und der Militärgrenze, betreffend die Bestellung eines beeideten Feldschutzpersonales und das Verfahren über Feldfrevel. Reichs-GesetzBlatt für das Kaiserthum Oesterreich. Jahrgang 1860, 6. sz. Ausgegeben und versendet am 2. Februar 1860.

5. 58. A m. k. pénzügy ministeriumnak 1867, május 23-án kelt rendelete Magyarország valamennyi törvényhatóságához az adóbehajtás kérdésében

6. 84. A magyar királyi honvédelmi ministerium körrendelete valamennyi törvényhatósághoz 1869.

7. 86. A honvédelmi m. kir. ministerium körrendelete, valamennyi törvényhatósághoz a sorozási ügy törvényszerű foganatositása végett követendő eljárás részletezése tárgyában. 1869. 


\section{Levéltári források}

1. Magyar Nemzeti Levéltár Országos Levéltára, Belügyminisztériumi iratok K150 C/ Általános iratok 117. csomó 17731/1871.-Arad vármegye; 20171/1871.-Aranyosszék; 21799/1871.; 28287/1871.-Bars vármegye; 31913/1871.-Békés vármegye; 17803/1871.Csanád vármegye; 21068/1871.; 27282/1871.-Csongrád vármegye; 21272/1871.Doboka vármegye; 22026/1871.-Felső-Fehér vármegye; 21800/1871.-Fogaras vidék; 20826/1871.-Sáros vármegye; 21798/1871.-Zala vármegye; 118. 22592/1871.-Bereg vármegye; 23816/1871.; 32032/1871.; 32051/1871.-Gömör és Kis-Hont vármegye; 28726/1871.;31986/1871.- Hont vármegye;23891/1871.-Hunyad vármegye;22499/1871.Kővár vidék; 22187/1871.-Közép-Szolnok vármegye; 22336/1871.-Veszprém vármegye; 233. 30937/1871.; 28463/1873.-Moson vármegye

Dr. Pétervári Máté a Szegedi Tudományegyetem Magyar Jogtörténeti Tanszékének adjunktusa, aki doktori fokozatát 2018-ban szerezte A járások kialakitása Magyarországon az 1870:XLII. tc. alapján című doktori értekezésével Dr. Varga Norbert egyetemi docens témavezetése mellett. Kutatásai a közigazgatástörténet egyes kérdéseire terjednek ki, valamint a PhD-fokozat megszerzését követően a csődjog történetének témaköréből jelentek meg tanulmányai. Az értekezése elkészítése során a Magyar Nemzeti Levéltár Országos Levéltárának dualizmus kori belügyminiszteri iratanyagának egyes fondjait dolgozta fel, amelynek segítségével a járási szervezet polgári kori átszervezésének bemutatására törekedett. E témakör vizsgálata hiánypótló a közigazgatás-történeti kutatásokra nézve, mivel a dualizmus kori vármegyékkel és törvényhatósági jogú városokkal foglalkozó tudományos eredményeket egy a közelmúltban ismét aktuálissá váló szegmenssel egészítheti ki. 